\title{
Welcome message from the organizers at the 1st Energy Informatics. Academy Conference Asia (El.A Asia 2021)
}

Zheng $\mathrm{Ma}^{1 *}$, Birte Holst Jørgensen ${ }^{2}$, Guangchao $\mathrm{Chen}^{3}$ and Bo Nørregaard Jørgensen ${ }^{4}$

From 1st Energy Informatics.Academy Conference Asia

Beijing, China . 29-30 May 2021

\author{
*Correspondence: zma@mmmi.sdu. \\ $\mathrm{dk}$ \\ ${ }^{1}$ SDU Center for Health Informatics \\ and Technology, the Maersk \\ Mc-Kinney Moller Institute, \\ University of Southern Denmark, \\ Odense, Denmark \\ Full list of author information is \\ available at the end of the article
}

Dear readers,

The 1st Energy Informatics. Academy Conference Asia (EI.A Asia 2021) (EnergyInformatics.Academy, 2021a) has collected great contributions from researchers and practitioners in various scientific, technological, engineering and social fields to disseminate original research on the application of digital technology and information management theory and practice to facilitate the global transition towards sustainable and resilient energy systems.

With the whole technical program committee's effort, in total 25 high-quality papers (including 21 full papers and 3 poster abstracts) were accepted and presented at the conference.

This supplement of the proceedings of Energy Informatics. Academy (EI.A) Asia 2021 includes 21 full papers from the EI. A Asia 2021 conference submission. Meanwhile, the 3 poster abstracts from the EI. A Asia 2021 conference submission and 10 from the co-located EI. A - SDC Asia 2021 Ph.D. workshop are included in the 'Abstracts from the Energy Informatics. Academy Asia 2021 conference and PhD workshop'.

The 21 full papers cover 7 important aspects of the energy informatics domain (shown in Table 1):

- Energy systems

- Energy in buildings

- Energy communities

- Electric Vehicles

- Energy in industry

- Energy markets

- Energy policy \& regulation

(c) The Author(s). 2021 Open Access This article is licensed under a Creative Commons Attribution 4.0 International License, which permits use, sharing, adaptation, distribution and reproduction in any medium or format, as long as you give appropriate credit to the original author(s) and the source, provide a link to the Creative Commons licence, and indicate if changes were made. The images or other third party material in this article are included in the article's Creative Commons licence, unless indicated otherwise in a credit line to the material. If material is not included in the article's Creative Commons licence and your intended use is not permitted by statutory regulation or exceeds the permitted use, you will need to obtain permission directly from the copyright holder. To view a copy of this licence, visit http://creativecommons.org/licenses/by/4.0/. 
Table 1 Themes of the 21 full papers from Energy Informatics. Academy (El.A) Asia 2021 conference

\begin{tabular}{|c|c|}
\hline Theme & Paper title \\
\hline \multirow[t]{3}{*}{ Energy systems } & A Scoping Review of Deep Neural Networks for Electric Load Forecasting \\
\hline & $\begin{array}{l}\text { Advanced Voltage Control Method for Improving the Voltage Quality of Low-Voltage Distribution } \\
\text { Networks with Photovoltaic Penetrations }\end{array}$ \\
\hline & $\begin{array}{l}\text { Optimization of district heating production with thermal storage using mixed-integer nonlinear pro- } \\
\text { gramming with a new initialization approach }\end{array}$ \\
\hline \multirow[t]{3}{*}{ Energy in buildings } & $\begin{array}{l}\text { Climatization and Luminosity Optimization of Buildings Using Genetic Algorithm, Random Forest, and } \\
\text { Regression Models }\end{array}$ \\
\hline & A QR code based framework for auto-configuration of loT sensor networks in buildings \\
\hline & $\begin{array}{l}\text { A Digital Twin Framework for Improving Energy Efficiency and Occupant Comfort in Public and } \\
\text { Commercial Buildings }\end{array}$ \\
\hline \multirow[t]{3}{*}{ Energy communities } & Software toolchain to enhance the management and integration of a sustainable campus model \\
\hline & Web-based platform for the management of citizen energy communities and their members \\
\hline & An Overview of Digitalization for the Building-to-Grid Ecosystem \\
\hline \multirow[t]{4}{*}{ Electric Vehicles } & $\begin{array}{l}\text { Joint Optimal Allocation of Electric Vehicle Charging Stations and Renewable Energy Sources } \\
\text { Including } \mathrm{CO}_{2} \text { Emissions }\end{array}$ \\
\hline & $\begin{array}{l}\text { A generic agent-based framework for modeling business ecosystems: a case study of electric vehicle } \\
\text { home charging }\end{array}$ \\
\hline & Electric Vehicles as Distribution Grid Batteries: A Reality Check \\
\hline & $\begin{array}{l}\text { Methodology for identifying technical details of Smart Energy Solutions and Research Gaps in Smart } \\
\text { Grid: An Example of Electric Vehicles in the energy system }\end{array}$ \\
\hline \multirow[t]{3}{*}{ Energy in industry } & Greenhouse Industry 4.0 - Digital Twin Technology for Commercial Greenhouses \\
\hline & A Multi-objective Optimization Platform for Artificial Lighting System in Commercial Greenhouses \\
\hline & Agent Based Coordination Protocol for System of Cyber-Physical Systems \\
\hline \multirow[t]{3}{*}{ Energy markets } & Local Energy Markets - An IT-architecture Design \\
\hline & $\begin{array}{l}\text { Industrial consumers' electricity market participation options: A case study of an industrial cooling } \\
\text { process in Denmark }\end{array}$ \\
\hline & Analysis and forecasting of crude oil price based on the variable selection-LSTM integrated model \\
\hline \multirow{2}{*}{$\begin{array}{l}\text { Energy policy \& } \\
\text { regulation }\end{array}$} & Evaluating the $\mathrm{CO} 2$ abatement effects of low-carbon city policy in China: A quasi-natural experiment \\
\hline & $\begin{array}{l}\text { Digitalisation Potentials in the Electricity Ecosystem: Lesson learnt from the Comparison between } \\
\text { Germany and Denmark }\end{array}$ \\
\hline
\end{tabular}

The presentations for these 21 full papers and 6 keynote speeches (shown in Table 2) are recorded and available via EnergyInformatics. Academy YouTube channel (EnergyInformatics.Academy, 2021b; EnergyInformatics.Academy, 2021c).

Sincerely,

General Chairs

Bo Nørregaard Jørgensen, University of Southern Denmark, Denmark

Table 2 Six keynote speeches at the Energy Informatics. Academy (El.A) Asia 2021 conference

\begin{tabular}{|c|c|c|}
\hline Keynote speech title & Speakers & Affiliation \\
\hline $\begin{array}{l}\text { International research collaboration - a stepping } \\
\text { stone for the green transition }\end{array}$ & $\begin{array}{l}\text { Dr. Thomas Trøst } \\
\text { Hansen }\end{array}$ & $\begin{array}{l}\text { Innovation Center Denmark Shanghai, } \\
\text { China }\end{array}$ \\
\hline Cybersecurity for the future power system & Prof. Ming Ni & NARI Technology Inc., China \\
\hline Vehicle-to-grid and blockchain application & Dr. Ye Yang & $\begin{array}{l}\text { State Grid Electric Vehicle Charging } \\
\text { Service Corporation, China }\end{array}$ \\
\hline $\begin{array}{l}\text { General, powerful, and scalable management of } \\
\text { energy flexibility with FlexOffers }\end{array}$ & $\begin{array}{l}\text { Prof. Torben } \\
\text { Bach Pedersen }\end{array}$ & Aalborg University, Denmark \\
\hline Smart buildings and energy efficiency & $\begin{array}{l}\text { Prof. Xiaoyu } \\
\text { Zhao }\end{array}$ & $\begin{array}{l}\text { Tongfang Technovator International } \\
\text { Limited Corp, China }\end{array}$ \\
\hline The Future Directions of Energy Informatics & Prof. Rick Watson & University of Georgia, USA \\
\hline
\end{tabular}


Guangchao Chen, University of Chinese academy of sciences, China

Birte Holst Jørgensen, Technical University of Denmark, Denmark

Program Committee Chair

Zheng Ma, University of Southern Denmark, Denmark

Technical Program Committee Chairs

Hongbo Duan, University of Chinese academy of sciences, China

Qiuwei Wu, Technical University of Denmark, Denmark

Yun Lin, Harbin Engineering University, China

\section{Abbreviations}

El.A Asia 2021: The 1st Energy Informatics. Academy Conference Asia; El.A: Energy Informatics.Academy

\section{Acknowledgments}

Not applicable.

\section{About this supplement}

This article has been published as part of Energy Informatics Volume 4, Supplement 2 2021: Proceedings of the Energy Informatics.Academy Conference Asia 2021. The full contents of the supplement are available at https:// energyinformatics.springeropen.com/articles/supplements/volume-4-supplement-2.

\section{Authors' contributions}

All authors read, commented, and approved the final manuscript.

\section{Funding}

Publication costs were covered by the Energy Informatics. Academy (El.A) Asia 2021 Conference Organizers.

Availability of data and materials

Not applicable.

\section{Declarations}

Ethics approval and consent to participate

Not applicable to this paper.

\section{Consent for publication}

Not applicable to this paper.

Competing interests

The authors declare that they have no competing interests.

\section{Author details}

${ }^{1}$ SDU Center for Health Informatics and Technology, the Maersk Mc-Kinney Moller Institute, University of Southern Denmark, Odense, Denmark. ²Department of Wind Energy, Society, Market and Policy, Technical University of Denmark, Roskilde, Denmark. ${ }^{3}$ College of Materials Sciences and Opto-Electronic Technology, University of Chinese academy of sciences, Beijing, China. ${ }^{4}$ SDU Center for Energy Informatics, the Maersk Mc-Kinney Moller Institute, University of Southern Denmark, Odense, Denmark.

Published: 24 September 2021

\section{References}

EnergyInformatics.Academy (2021a) El. A Asia 2021- 1st Energy Informatics. Academy Conference Asia, Beijing https:/www. energyinformatics.academy/eia-asia-2021-conference Accessed 22 June 2021

EnergyInformatics.Academy (2021b) The Energy Informatics. Academy Asia. conference https://www.youtube.com/pla ylist?list=PLeFn4XFYdKdtlgYT96vNwddywMZObo9S_Accessed 22 June 2021

Energylnformatics.Academy (2021c) The Energy Informatics. Academy Asia. PhD workshop https://wwwyoutubecom/pla ylist?list=PLeFn4XFYdKdtOL-MJ08uVzmwlhvcYuw-v Accessed 22 June 2021

\section{Publisher's Note}

Springer Nature remains neutral with regard to jurisdictional claims in published maps and institutional affiliations. 